\title{
Multiple palmar pits and basal cell carcinomas
}

\section{José Juan Pereyra-Rodríguez MD PhD, José Bernabeu-Wittel MD, Julián Conejo-Mir MD PhD}

Previously published at www.cmaj.ca

A 37-year-old man presented with a history of small lesions on his back, chest and face that had increased in number over three years. His medical, dental and family history was unremarkable. On examination, he had multiple brown papules, a few millimetres in diameter, on his back, chest and face (Figure 1A). Under dermoscopy, the lesions included multiple brown-greyish dots and globules. Numerous palmar pits were seen, each flesh- or redcoloured and measuring 1-3 mm in diameter (Figure 1B). On dermoscopy of the palmar pits, whitish borders and vascular structures distributed in parallel lines of red globules were found.

Some of the lesions on the cheek and face were removed and were found to be basal cell carcinomas on histopathology. Orthopantomography (radiography of the jaw) showed multiple odontogenic keratocysts. A diagnosis of Gorlin syndrome, a rare autosomal-dominant cancer syndrome, was made, although the family history was negative. During follow-up, more basal cell carcinomas appeared, which were treated with excision, cryotherapy or topical application of imiquimod.

Palmar and plantar pits appear as punctiform depressions in the skin of palms and soles of feet. These changes are caused by a partial or complete absence of the stratum corneum. They are usually asymmetric, flesh-, pink- or redcoloured, and range from 2 to $3 \mathrm{~mm}$ in diameter and 1 to $3 \mathrm{~mm}$ in depth. In Gorlin syndrome, pits appear in 30\%-65\% of patients by the age of 10 years and in $85 \%$ of patients over the age of 20 years. ${ }^{1}$ The presence of three or more palmar pits constitutes a major diagnostic criterion in Gorlin

From the Department of Dermatology, Virgen del Rocio University Hospital, Sevilla, Spain

\section{CMAJ 2010. DOI:10.1503/cmaj.090884}

syndrome. ${ }^{2}$ Palmar pits may also be seen in patients with some common conditions, such as keratosis punctata or psoriasis, as well as in patients with rarer conditions, such as Darier disease, generalized follicular hamartoma or reticulate acropigmentation of Kimura. ${ }^{3}$

When palmar pits are discovered, particularly in a child, a careful physical examination is mandatory. The presence of multiple basal cell carcinomas associated with pits in a young person should raise suspicion for Gorlin syndrome, even if the family history is negative. In this situation, radiologic studies should be undertaken to look for skeletal anomalies such as odontogenic keratocysts, which may be present in up to $92 \%$ of patients. ${ }^{4}$ Early diagnosis is important because these patients are at higher risk of developing multiple neoplasms, such as medulloblastomas ${ }^{2}$ or meningiomas. ${ }^{1,5}$

This article has been peer reviewed.

Competing interests: None declared.

\section{REFERENCES}

1. Lo Muzio L. Nevoid basal cell carcinoma syndrome (Gorlin syndrome). Orphanet J Rare Dis 2008;3:32.

2. Kimonis VE, Goldstein AM, Pastakia B, et al. Clinical manifestations in 105 persons with nevoid basal cell carcinoma syndrome. Am J Med Genet 1997;69:299-308.

3. Jackson SM, Nesbitt LT. Differential diagnosis for the dermatologist. Leipzig (DE): Springer; 2008. p. 185.

4. Lo Muzio L, Nocini PF, Savoia A, et al. Nevoid basal cell carcinoma syndrome. Clinical findings in 37 Italian affected Individuals. Clin Genet 1999;55:34-40.

5. Kimonis VE, Mehta SG, Digiovanna JJ, et al. Radiological features in 82 patients with nevoid basal cell carcinoma (NBCC or Gorlin) syndrome. Genet Med 2004;6:495-502. 